\title{
PERAN GEMBALA SIDANG DALAM MENGAJAR DAN MEMOTIVASI UNTUK MELAYANI TERHADAP PERTUMBUHAN ROHANI PEMUDA
}

\author{
Talizaro Tafonao \\ Sekolah Tinggi Teologi Kadesi Yogyakarta \\ Weron, Balong, RT/RW 002/012, Umbulharjo, Cangkringan, Sleman \\ Tromol Pos 4 Kaliurang (55585) Yogyakarta-Indonesia \\ Email: talizarotafonao@gmail.com
}

\begin{abstract}
Talizaro Tafonao. The Role of Pastors In Teaching And Motivating To Serve Against Youth Spiritual Growth. One important indicator that must be known by young people is to understand the duty of the pastor as a teacher and a motivator. Through this paper, researchers describe the duties of a pastor in teaching and motivating young people to engage in ministry. In finding the answers of this study, researchers used quantitative research methods with descriptive research type. After conducted field research and data processing using SPSS 19 program with the result are: First, Based on correlation analysis (r) Spearmen model, then obtained correlation analysis results that there is correlation between the influences of the role of pastor in teaching with spiritual growth of youth GKII Shalom Kalasan of 0.461. Second, Based on correlation analysis results (r) Spearmen model, then obtained correlation analysis results that there is a correlation between the influences of the role of pastor in teaching with spiritual growth of GKII Shalom Kalasan youth by 0.619. Third, Based on correlation analysis result (r) Spearmen model, then obtained correlation analysis result that there is correlation between influence of role of pastor in teaching and motivating youth to serve with spiritual growth of GKII Shalom Kalasan youth equal to 0,526 . The hypothesis in this research is that there is influence of the role of pastor in teaching and motivating young people to serve the spiritual growth of GKII youth Shalom Kalasan. Based on the above analysis, the hypothesis is accepted.
\end{abstract}

Keywords: Pastor, Teaching, Motivating, Spiritual, Youth

\begin{abstract}
ABSTRAK: Talizaro Tafonao. Peran Gembala Sidang Dalam Mengajar Dan Memotivasi Untuk Melayani Terhadap Pertumbuhan Rohani Pemuda. Salah satu indikator penting yang harus diketahui oleh kaum muda adalah memahami tugas gembala sidang sebagai pengajar dan motivator. Melalui tulisan ini peneliti mendreskripsi tugas seorang gembala sidang dalam mengajar dan memotivasi kaum muda untuk terlibat dalam pelayanan. Dalam menemukan jawaban penelitian ini maka peneliti menggunakan metode penelitian kuantitatif dengan jenis penelitian deskriptif. Setelah dilakukan penelitian lapangan serta pengolahan data dengan menggunakan program SPSS 19 dengan hasil adalah: Pertama, Berdasarkan hasil analisis korelasi (r) model Spearmen, maka diperoleh hasil analisis korelasi bahwa ada korelasi antara pengaruh peran gembala sidang dalam mengajar dengan pertumbuhan rohani pemuda GKII Shalom Kalasan sebesar 0,461. Kedua, Berdasarkan hasil analisis korelasi (r) model Spearmen, maka diperoleh hasil analisis korelasi bahwa ada korelasi antara pengaruh peran gembala sidang dalam mengajar dengan pertumbuhan rohani pemuda GKII Shalom Kalasan sebesar 0,619. Ketiga, Ketiga, Berdasarkan hasil analisis korelasi (r) model Spearmen, maka diperoleh hasil analisis korelasi bahwa ada korelasi antara pengaruh peran gembala sidang dalam mengajar dan memotivasi kaum muda untuk melayani dengan pertumbuhan rohani pemuda GKII Shalom Kalasan sebesar 0,526. Hipotesis dalam penelitian ini adalah ada pengaruh peran gembala sidang dalam mengajar dan memotivasi kaum muda untuk melayani terhadap pertumbuhan rohani kaum muda GKII Shalom Kalasan. Berdasarkan analisis di atas, hipotesis tersebut diterima.
\end{abstract}

Kata kunci: Gembala, Mengajar, Memotivasi, Rohani, Pemuda.

\section{PENDAHULUAN}

Berdasarkan 1 Timotius 4:6-11, gembala sidang adalah pelaksana tugas mengajar. Mengajar adalah upaya pengajar untuk mentransfer pengeta- huan, pandangan, keyakinan, dogma, dan doktrin atau teologi yang dimilikinya kepada peserta didik. Dalam pengertian itu, tugas utama peserta didik ialah menguasai bahan pengajaran yang disampaikan 
oleh, mengetahuinya dengan seksama agar dapat mengungkapkan ulang serta memahaminya secara kognitif (Sidjabat, 2011, p. 10). Mengajar adalah salah satu tugas dari gembala sidang. Tugas ini sama pentingnya dengan tugas penggembalaan. Tentu seorang gembala sidang harus mampu mendesain cara menyampaikan firman Tuhan secara baik. Dari penjelasan di atas sangat jelas tugas gembala dalam konteks kerohanian dan Paulus juga menegaskan bahwa pekerjaan yang paling indah ialah mereka yang menghendaki jabatan penilik atau gembala (1 Tim. 3:1).

Seorang pelayan Tuhan yang menghendaki pekerjaan seorang gembala haruslah orang yang telah mengambil keputusan untuk menyerahkan seluruh hidupnya untuk melayani Kristus. Jadi, tugas seorang gembala sidang adalah: (a) mengingatkan kaum muda pada ajaran yang sehat (1 Tim. 4:6). Dalam ayat ini Paulus sedang memberikan nasihat kepada anak didiknya yaitu Timotius yang ditugaskan sebagai seorang gembala di kota Efesus (1 Tim. 1:2). Nasihat-nasihat yang diberikannya mencakup kehidupan pribadi dan pelayanan Timotius, arahanarahan mengenai berbagai urusan dan persoalan penggembalaan di gereja, dan dorongan untuk tetap mempertahankan kemurnian Injil dengan standarnya yang kudus, bebas dari berbagai pencemaran. Salah satu persoalan yang ada di jemaat di Efesus adalah jemaat Efesus pada waktu itu lebih sibuk mendengarkan dongeng dari pada mendengarkan firman Tuhan; (b) Gembala menasihati kaum muda pada ajaran yang sehat (1 Tim. 4:11). Kata dasar dari kata "beritakanlah" adalah kata "berita." Menurut Sutanto $(2006$, p. 604, 784) kata beritakanlah dalam bahasa Yunani adalah $\pi \alpha \rho \alpha \gamma \varepsilon \lambda \lambda \omega$ paraggello artinya memerintahkan, menyuruh, berpesan, memberitakan. Latar belakang kalimat atau ayat ini dapat dilihat dalam 1 Timotius 1:3. Artinya banyak pengajar-pengajar yang tidak bertanggung jawab atas ajarannya khususnya di jemaat di Efesus seperti yang di ungkapkan pada 1 Timotius 1:7-8. Ayat tersebut yang menjadi dasar bagi Paulus sehingga ia berpesan kepada Timotius supaya pengajar-pengajar sesat yang ada di tengah-tengah jemaat di Efesus bisa teratasi dengan baik melalui nasihat Timotius kepada jemaat berdasarkan firman Tuhan yang murni. Tujuan nasihat menurut Rasul Paulus harus didasarkan pada kasih yang murni seperti di ungkapkan pada 1 Timotius 1:5. Artinya dengan tindakan seperti ini maka jemaat akan tertolong dari pengaruh-pengaruh ajaran sesat; (c) Gembala mengajar kaum muda sesuai dengan ajaran yang sehat. "Beritakanlah dan ajarkanlah semuanya itu" (1 Tim. 4:11). Kata ajarkanlah dalam bahasa Yunani adalah $\delta l \delta \alpha \sigma \kappa \omega$ didas$k o$ artinya mengajar (Susanto, 2006b, p. 204). Kata dasar dari kata "mengajar" adalah kata "ajar." Kata benda Yunani yang dipakai ialah didaskalia. Kata benda tersebut berjenis akusatif feminim tunggal. Kata ini berasal dari kata $\delta l \delta \alpha ́ \sigma \kappa \omega$ yang artinya mengajar atau peringatan (Moulton, 2009, p. 90). Tujuan Paulus kepada Timotius dalam ayat ini adalah untuk mengajarkan ajaran yang sehat. Istilah sehat dan khususnya dalam kombinasi dengan ajaran atau "perkataan" adalah salah satu ciri khas surat-surat Pastoral (1 Tim. 6:3; 2 Tim. 1:13; 4:3; Tit. 1:9, 13; 2:1, 2,8) (Rudy, 2008, p. 9). Jadi dalam konteks ini ada ajaran yang tidak sehat dalam jemaat Efesus, sehingga Paulus menentang ajaran-ajaran palsu, seperti yang ada dalam 1 Tim. 4:1-5. Dengan kata lain bahwa Injil yang diajarkan oleh Paulus dapat disebut sebagai ajaran yang sehat, karena melalui pengajaran yang sehat, hidup manusia yang rusak karena dosa bisa dipulihkan kembali (Rudy, 2008, p. 9). Maksud ajarkanlah semuanya itu menurut peneliti adalah mengajar Injil keselamatan yang ada dalam Yesus Kristus, (1 Tim. 1:11).

Kemudian menurut 1 Timotius 4:1-16 gembala dituntut untuk menjadi teladan. Timotius harus menjadi teladan dari kehidupan Kristen. Ia dituntut untuk memberikan teladan tentang apa yang diajarkan, yang diwujudkan di dalam kehidupan sehari-hari, sehingga orang tidak akan memandang dia rendah. Sebagai seorang pengajar Timotius dituntut untuk memberikan teladan tentang apa yang diajarkan, yang diwujudkan di dalam kehidupan sehari-hari. Dengan menjadi teladan, ia akan dihormati oleh 
orang-orang percaya. Keteladanan Timotius harus tampak dalam enam aspek, yaitu:

(a) Keteladanan dalam perkataan (1 Tim. 4:12). Dalam ayat ini, Timotius diperintahkan untuk menjadi teladan dalam perkataan, baik yang ia sampaikan secara pribadi kepada beberapa orang maupun yang disampaikan di depan umum. Perkataan ini di sini berhubungan erat dengan pengajaran tentang doktrin. Karena kata $\varepsilon \varpi v \lambda o, \gamma \omega$ (en logoi) dalam bentuk tunggal maka yang dimaksudkan adalah seluruh perkataan Timotius harus menjadi panutan atau teladan bagi orang lain. Sekalipun Timotius ini masih muda, namun Paulus menghendaki Timotius menjadi teladan bagi orang-orang percaya melalui perkataan. Rudy (2008, p. 14) memperkirakan bahwa usia Timotius pada waktu menerima surat $1 \mathrm{Ti}$ motius adalah 15 tahun (bdk. II Tim.1:5; 3:15 yang menginggung masa kecil Timotius);

(b) Keteladanan dalam tingkah laku. Paulus sangat menghendaki Timotius dapat menjadi teladan bagi orang-orang percaya, yaitu dalam ting-kah laku. Tingkah laku dalam bahasa Yunani "Anastrophe" yang memiliki makna yakni: cara hidup, perilaku, sikap (Susanto, 2006a, p. 69). Mengandung arti bahwa kehidupan orang percaya harus dikendalikan oleh firman Allah, dalam tingkah laku harus sabar, bertanggung jawab dan berintegritas. Kata integritas berasal dari bahasa Inggris yakni integrity, yang berarti menyeluruh, lengkap atau segalanya. Kamus Oxford menghubungkan arti integritas dengan kepribadian seseorang yaitu jujur dan utuh (http://sabda. org, 2014). Sedjaya (2004, p. 62) mengatakan bahwa integritasi adalah modal utama seorang pemimpin, namun sekaligus modal yang paling jarang dimiliki oleh pemimpin. Dari penjelasan di atas peneliti menyimpulkan bahwa salah satu indikator penting yang harus dimiliki oleh gembala sidang adalah memiliki kepribadian yang baik dan dapat dipercaya, komitmen, tanggung jawab, kejujuran, kebenaran, dan kesetiaan. Artinya kehidupan seseorang akan menjadi dipercaya, apabila perkataannya sejalan dengan perbuatannya; (c) Keteladanan dalam kasih. Paulus merindukan Timotius untuk membagikan kasih itu kepada siapa saja tanpa harus ada motivasi lain. Yesus telah membutikkan kasih itu kepada semua orang dengan cara mati di kayu salib (1 Kor.15:3). Menurut McDermott (2001, p. 69) kasih adalah karakteristik Kristen terpenting dan paling jelas. Kata kasih dalam Bahasa Yunani $\alpha \gamma \alpha \pi \eta$ (agape) artinya kasih yang sejati, kasih illahi, kasih tanpa syarat, kasih yang rela berkorban, kasih yang tidak akan digoyahkan oleh karena situasi-kondisi yang bagaimana pun buruknya (Susanto, 2006a, p. 6). Menunjuk kepada motivasi kehidupan seseorang dan hanya Tuhan yang dapat memampukan setiap pribadi untuk mengasihi dengan kasih “Agape”. Dalam kasih (Agape) manusia dimampukan mendoakan musuh-musuhnya dan mampu memberkati orang yang membencinya. Agape adalah kasih yang tidak mementingkan diri, tidak kenal pamrih, tetapi motifnya adalah kesediaan untuk berkorban demi orang lain yang membutuhkan kasih tersebut (Ayub, 2011, p. 190). Menurut Nygren (1982, p. 120), Kasih agape bekerja untuk memberikan kebaikan bagi orang lain tanpa memperdulikan apa yang dirasakannya sendiri. Kasih agape tidak bisa diterjemahkan sebagai suatu perasaan atau perhatian. Manusia mengasihi Allah dan sesama karena adanya kebutuhan dalam dirinya, namun kasih Allah kepada manusia adalah gift-love. Hanya Allah yang sanggup melimpahkan gift-love. Allah sendiri tidak membutuhkan apa-apa, tetapi adalah perintah Allah agar manusia mengalami dan memiliki kasih agape. Ia menghendaki agar manusia mengasihi Allah dan sesama dengan kasih agape (Roberts, 1988, p. 32);

(d) Keteladanan dalam kesetiaan. Kesetiaan itu diumpamakan seperti suami istri harus meliputi kesetiaan pada hal-hal kecil yang ada pada kehidupan mereka. Agar keduanya dapat hidup dengan dipenuhi cinta, kasih sayang, penghormatan dan ketulusan dalam hati, tidak saling menyakiti satu sama lain. Kesetiaan berarti perjuangan, anugerah, pengorbanan, dan kesabaran. Kesetiaan dalam bahasa Yunani "Pistis" kepercayaan, iman, setiaan kepada Allah 
dan firman-Nya. Dalam bahasa aslinya kata "iman" dan "kesetiaan" memiliki akar kata yang sa-ma (pistis) (Susanto, 2006a, p. 641). Kesetian adalah pemberitaanya dan diterima sepenuhnya. "Pemberitaan tersebut bukan hanya suatu perkataan, melainkan berlandaskan pada kata-kata yang di ucapkan Kristus (Luk. 19:10), dan memiliki nilai yang sama dengan kebenaran Injil (Everett, 2008, p. 23). Kesetiaan berarti selalu bertanggung jawab dalam pelayanan. Artinya pemimpin adalah teladan iman dan kesetiaan. Itu berarti pemimpin perlu mendasari hidupnya pada iman dan kesetian kepada Tuhan;

(e) Keteladanan dalam kesucian. Kata benda kesucian dalam 1 Timotius 4:12 diterjemahkan dari kata $\varepsilon \varpi v \alpha \bar{\gamma} v \varepsilon l, \alpha$ (en hagneiai) yang berarti dalam kemurnian atau kesucian. Semua terjemahan bahasa Inggris menggunakan kata purity yang berarti kemurnian sikap yang harus ditunjukkan oleh Timotius di dalam seluruh kehidupannya. Paul M. Zehr (2002, p. 208) menjelaskan kata 'kemurnian' sebagai hal yang perlu dijaga oleh seorang pelayan muda, khususnya dalam hal dosa seksual dan cara memperingati seseorang. Kata "murni" (Yunani Hagnos atau amiantos) berarti bebas dari semua noda hal-hal cabul. Kata ini menekankan agar mengendalikan diri dari dan menjauhi semua tindakan dan rangsangan seksual yang dapat menajiskan kemurnian seseorang di hadapan Allah. Maksudnya adalah dipisahkan untuk Allah mensyaratkan adanya pemisahan diri dari kecemaran. Dalam konteks ini Paulus menghendaki Timotius sebagai gembala yang masih muda tetap menjaga kemurnian atau kesucian hidup di hadapan Allah dan manusia, melaui percakapan, bahasa, kasih, iman, dan perbuatan; (f) Keteladanan dalam ketekunanan. Seorang pelayan seperti Timotius harus dapat mengatasi segala sesuatu yang berpotensi untuk menyulitkan, mencemarkan, menghalangi, bahkan menggagalkan pelayanan yang dilakukannya. Dalam hal ini, ketekunan menjadi kata kunci yang harus Timotius cermati dan perhatikan. Menurut Yudho (2009, p. 52) mengatakan bahwa ketekunan adalah sesuatu yang mahal dan sangat berguna bagi usaha atau bisnis. Jadi, dalam konteks ini Timotius tidak boleh membiarkan umurnya menjadi perintang bagi dirinya atau batu sandungan bagi orang lain. Karena itu, ia perlu menjadi teladan dalam perkataan, tingkah laku, kasih, dan kesuciannya (ayat 12). Selain itu, Timotius juga diminta untuk tetap bertekun dalam pembacaan dan pengajaran nas-nas Kitab Suci di antara jemaatnya (ayat 13), tidak lalai dalam mempergunakan karunia yang Tuhan berikan padanya (ayat 14), dan sungguh-sungguh membiarkan hidupnya dikuasai oleh hal-hal yang baik, sehingga kemajuannya nyata bagi orang-orang di sekitarnya (ayat 15). Timotius juga harus mengawasi dirinya sendiri dan ajarannya (ayat 16). Kesemuanya itu harus dilakukannya dalam ketekunan (ayat 16). Ada dua unsur yang tidak boleh dilupakan dalam hal bertekun; itulah "sungguh-sungguh" dan "terus-menerus". Kata bertekun dalam ayat tersebut digunakan istilah prosekho (Yunani) kata ini lebih tepat diterjemahkan sebagai memberi perhatian atau mengutamakan (Susanto, 2006a, p. 677). Dengan kata lain Paulus mengatakan kepada Timotius bahwa sebagai seorang pelayan ada hal yang harus diutamakan atau diberi perhatian khusus dengan sungguh-sungguh dan terus menerus. Ada empat hal tentang bertekun dalam hal ini: Pertama, bertekun dalam membaca kitab-kitab suci, kedua, bertekun dalam membangun dengan firman Tuhan, ketiga, bertekun dalam mengajarkan firman Tuhan, keempat, bertekun dalam melakukan kebenaran dalam hidup sehari-hari (ay 15).

Berdasarkan 1 Timotius 4:1-16 peran gembala sidang adalah memotivasi kaum muda untuk melayani. Dalam hal ini berdasarkan 1 Timotius 4:616 gembala berperan sebagai pendorong. Ada dua macam gembala dalam Alkitab. Pertama, orang yang menggembalakan ternak. Kedua, orang yang mengasuh dan membina manusia, yaitu gembala yang bersifat ilahi dan fana. Asuhan terhadap sesama makhluk fana bisa bersifat politik ataupun rohani (Walls, 2002). Gembala yang baik adalah gembala yang mengenal ternak yang digembalakannya secara utuh. Namun, agar seorang gembala mampu mengenal ternaknya secara utuh, maka mau tidak mau, ia harus memiliki hubungan emosional yang intim de- 
ngan ternak gembalaannya. Selain dari pada itu juga gembala harus mampu memotivasi domba-domba, agar domba-dombanya memiliki semangat untuk hidup termasuk menjalankan hidup sehari-hari. Kata motivasi sebenarnya berasal dari bahasa Latin, yakni movere yang berarti "menggerakkan" (to move) (Winardi, 2007, p. 1). Kata "movere" menunjuk kepada sesuatu yang aktif, dinamis dan berkembang atau progresif. Jadi, apa bila seseorang ingin menjadi pemimpin yang efektif dan berhasil, ia harus lebih memiliki motivasi yang besar untuk memenuhi kebutuhan orang lain. Dalam hal ini atasan harus mampu mendorong bawahan untuk mengoptimalkan potensi yang ada" (Greeleaf, 1990, p. 360).

Kemudian gembala memberikan kepercayaan dengan mendelegasikan tugas. Pendelegasikan tugas adalah penyerahan wewenang dari atasan kepada bawahan dalam tugas tertentu dengan kewajiban mempertanggung jawabkan kepada yang menugasi. Tidak semua pemimpin memiliki keberanian untuk mendelegasikan sebuah tugas kepada bawahannya, jemaat atau anak didik, atau anak rohaninya. Paulus mendelegasikan tugas kepada Timotius untuk memimpin sebuah pelayanan atau memimpin sebuah gereja. Sekalipun usia Timotius masih sangat muda, bahkan dianggap masih sangat labil dan belum matang secara psikologi, tetapi dalam kenyataan ini, Paulus tetap berani untuk mendelegasikan tugas penggembalaan kepada Timotius untuk mengurus jemaat di Efesus.

Selain memberi pendelegasian, gembala juga memberi motivasi yang baik bagi murid. Timotius masih sangat muda ketika Paulus memberikan sebuah tanggung jawab untuk memimpin sebuah gereja di Efesus. Bagi orang Yahudi yang memegang filsafat bahwa orang yang tua adalah orang yang bijaksana, ini menjadi suatu kendala secara psikis terhadap Timotius yang tergolong masih sangat muda. Timotius sangat ketakutan dan merasa minder karena kemudaannya. Ia takut dan merasa dirinya tidak dihormati, tetapi Rasul Paulus memberi motivasi kepada Timotius bahwa "Jangan seorangpun menganggap engkau rendah karena engkau muda. Jadilah te- ladan bagi orang-orang percaya, dalam perkataanmu, dalam tingkah lakumu, dalam kasihmu, dalam kesetiaanmu dan dalam kesucianmu". (1 Tim. 4:12). Artinya usia muda bukan berarti harus dipandang sebelah mata. Para pembawa kabar sukacita bukan ditentukan dari kemudaannya, namun sejauh mana dia mengetahui, mengerti dan melakukan firman Tuhan dalam kesehariannya.

Peran berikutnya adalah memberi solusi pada murid (1 Tim. 4:14). Ayat ini menjadi bukti ketegasan Paulus secara khusus dalam memotivasi atau mendorong Timotius untuk sedapat mungkin menghindari hal-hal atau omongan yang tidak berkenan seperti celaan, hinaan dst. Paulus mengharapkan supaya Timotius siap sedia dalam penderitaan. Ayat 14 merupakan pernyataan iman Paulus sekaligus menjadi konsep iman yang terindah untuk diteladani, (bdk. 2 Tim 1:6. Paulus sangat mengenal Timotius, bahkan ia sangat mengenal kelemahan-kelemahan Timotius. Paulus sangat memahami dan sadar pada kenyataan tentang kelemahan Timotius. Semua itu tidak menyurutkan kepercayaan Paulus kepada Timotius bahwa ia bisa menjadi seorang pemimpin yang hebat. Paulus memberikan beberapa nasihat yang menjadi sebuah solusi bagi Timotius, yaitu jangan lalai dalam mempergunakan karunia yang ada padamu, yang telah diberikan kepadamu oleh nubuat dan dengan penumpangan tangan sidang penatua. Paulus mengetahui potensi yang dimiliki oleh Timotius supaya dia mampu memanfaatkan karunia itu bukan untuk menjadi seorang pengecut tetapi mempergunakan karunia dengan sebaik-baiknya (Blaiklock, 1981, p. 92). Paulus juga mengingatkan Timotius untuk tidak menjadi takut, karena Tuhan tidak memberi roh ketakutan tetapi roh keberanian. Kata karunia dalam bahasa Yunani adalah $\chi \alpha \rho \imath \sigma \mu \alpha$ (charisma). Artinya karunia sebagai pertanda kasih kurnia Allah (Susanto, 2006a, p. 811). Karuniakarunia ini haruslah digunakan dengan motivasi bukan kepentingan pribadi, tetapi karunia yang harus memuliakan Tuhan, (Nubantimo, 2009, p.46).

Berdasarkan 1 Timotius 4:6-10 gembala berperan sebagai pembina. Istilah "pembinaan" berasal 
dari kata dasar "bina". Menurut peneliti, mengajar itu mempunyai otoritas yang penting dalam hal mendidik seseorang. Lebar (2006, p. 30) menjelaskan bahwa seseorang membutuhkan khotbah maupun pengajaran, masing-masing dengan metodenya sendiri. Para gembala sidang terpanggil dan terlatih untuk berkhotbah. Para pengajar atau guru seharusnya terpanggil dan terlatih untuk mengajar. Artinya kedua tugas ini seharusnya diupayakan dalam konteks pelayanan di gereja supaya pendidikan itu bisa dirasakan oleh kaum muda. Kata engkau disitu menunjukkan kepada kordinator pemuda agar mereka terbina dengan baik.

Ada tiga tugas gembala dalam konteks pembinaan pemuda berdasarkan 1 Timotius 4:1-16: (a) Gembala mengajar pemuda di dalam Tuhan. Di dalam kitab Perjanjian Baru juga ada terdapat beberapa pelajaran mengenai pembinaan yang dilakukan untuk membina, mendidik dan mengajar pemuda di dalam Tuhan. Jika pemuda tidak dibina ataupun salah pembinaan, maka mereka bukan semakin dekat kepada Tuhan, tetapi semakin jauh dari Tuhan dan mereka hidup dalam pergaulan bebas. Pemuda harus dibina dengan baik agar menjauhkan diri dari dunia dan dosa, mempersatukan diri dengan kematian dan kebangkitan Kristus, menyerahkan dan mempersembahkan diri kepada Allah. Dengan kata lain, memiliki persekutuan yang intim dengan Kristus (I Yoh. 2:15-17); (b) Gembala memotivasi pemuda untuk tetap beribadah kepada Tuhan. Gereja dalam pelaksanaan pembinaan terhadap pemuda dapat dilakukan dengan pembinaan secara motivasi. Walaupun metode dan cara pembinaan begitu luas namun hal itu tidak cukup untuk lebih efektif dan efisien dalam mendewasakan kerohanian para pemuda. Itu sebabnya pemuda perlu dibina dengan baik dan dididik, agar pemuda mempunyai motivasi yang jelas dan memiliki karakter yang baik dalam kehidupannya. 1 Timotius 4:7b-8 - Latihlah dirimu beribadah.... Kata latih berarti latihan dan disiplin untuk menghasilkan sesuatu yang berdampak pada hidup kekekalan. Artinya Timotius dan semua orang Kristen harus beribadah. Yang dimaksud dengan ibadah di sini ialah: hidup yang berkenan pada Allah, yaitu hidup yang merupakan penghayatan iman dalam kata-kata dan perbuatan (Rudy, 2008, p. 38). Jadi, menurut hemat peneliti bahwa jika pemuda tidak dimotivasi untuk tetap beribadah kepada Tuhan maka pemuda semakin jauh dari Tuhan dan hidup seenaknya. (2 Tim. 2:22); (c) Gembala memotivasi untuk tetap berjuang dalam Tuhan. "Perkataan ini benar dan patut diterima sepenuhnya. Itulah sebabnya kita berjerih payah dan berjuang, karena kita menaruh pengharapan kita kepada Allah yang hidup, Juruselamat semua manusia, terutama mereka yang percaya". (1 Tim. 4:9-10). Kata menaruh pengharapan dalam bahasa Yunani $\varepsilon \lambda \pi \imath \zeta \omega$ elpizo. Jenis kata ini verb (kata kerja) artinya masa depan (future) $\varepsilon \lambda \pi \iota \omega$; aorist: $\eta \lambda \pi \imath \sigma \alpha$; perfek: $\eta \lambda \pi \iota \kappa \alpha)$ mengharapkan, berharap (www.sabda.org). Kata elpizo diungkapkan terutama kepercayaan, dalam arti merasa diri aman, terlindung, mempunyai kepastian. Akan tetapi sekaligus juga berarti menantikan, menginginkan. Dan justru karena hubungan dengan "percaya" itu, elpizo berarti mengharapkan penuh rasa sabar dan tabah hati. Elpizo dalam bahasa religius kitab suci ada kesamaan dan ada perbedaan dalam bahasa profan. Kesamaannya ialah orangnya berhadapan dengan masa depan, sedangkan perbedaannya terletak dalam sikap hati orang yang bersangkutan: dalam bahasa profan, orang yang "mengharapkan" masa depan itu masih dapat khawatir juga, sebaliknya dalam kitab suci ia tidak merasa bimbang dan takut tetapi hatinya mantap karena mempunyai pegangan sehingga dengan penuh kesadaran ia berani menghadapi masa depan (Syukur, 2004, p. 505-506). Jadi, dalam konteks ini Paulus mendorong Timotius untuk tetap berharap kepada Tuhan, sekalipun menghadapi banyak tantangan.

Pada masa kini banyak orang salah mengerti tentang gembala, bahkan ada orang beranggapan bahwa gembala itu terlalu rendah dan lingkup kekuasaannya sangat kecil sehingga banyak pelayan Tuhan sekarang ini selalu menghindar dari identitas gembala. Jika ditelusuri kata gembala dalam Alkitab ternyata gembala sering disebutkan dalam Alkitab, 
mulai dari Kitab Kejadian sampai Kitab Wahyu. Ada sekitar 84 ayat dalam Alkitab yang memuat tentang kata gembala. Paling banyak disebutkan dalam Perjanjian Lama sebanyak 67 ayat. Pertama sekali kata gembala disebutkan adalah dalam Kejadian 4:2 yaitu Habel. Habel orang pertama yang memiliki pekerjaan sebagai gembala (Tafonao, 2016, p. 5). Dalam tradisi Yahudi mengisahkan bahwa menjadi gembala adalah suatu pekerjaan yang amat mulia dan pekerjaan tersebut bisa dilakukan oleh pria dan wanita (Kej. 30:29; Kel. 2:16-19). Tetapi di samping itu, pekerjaan gembala adalah pekerjaan yang paling berat dan berbahaya (Kej. 31:38-40; 1 Sam. 17:3436; Yes. 31:34; Luk. 15:16). Kendatipun demikian, Pemazmur Daud dengan indah melukiskan tanggung jawab seorang gembala yang baik. Sebuah mazmur yang ditulis oleh Asaf menyebut Daud sebagai gembala atas umat Allah pada zaman dahulu. Maz. 23:16; 78:70-72. Selain dari pada itu, dalam Perjanjian Baru, Tuhan Yesus mengangkat para rasul, pekabar Injil, para pengajar dan gembala untuk memperlengkapi orang-orang Kudus untuk bertumbuh mencapai kedewasaan penuh. Begitu pentingnya, para gembala tersebut di dalam Yoh. 21: 15-17, sehingga Tuhan Yesus tiga kali memerintahkan Petrus: "Gembalakanlah domba-domba-Ku". Karena gembala secara khusus diangkat oleh Tuhan guna mengajar, membimbing anak-anak Tuhan untuk bertumbuh dengan berlandaskan pada firman Tuhan (Yoh. 21:15-19).

Selain persoalan di atas, peneliti juga menemukan beberapa persoalan lain berkaitan dengan tempat penelitian ini. Berdasarkan pengamatan dan wawancara yang dilakukan oleh peneliti di pemuda GKII Shalom adalah Pertama, selama ini kaum muda telah mendapat pengajaran dari gembala tetapi masih belum maksimal, sehingga ketika kaum muda diberikan tugas untuk melayani di persekutuan gereja dengan berbagai macam alasan untuk tidak melakukan tanggung jawab tersebut. Kedua, semua kaum muda memiliki talenta, namun tidak ada yang membina dan melatih secara berkala, sehingga talenta tersebut tidak dipergunakan dengan baik. Ketiga, efektivitas jangka panjang dan jangka pendek dari pela- yanan kaum muda sangat minim (Agan, 2016). Bila dicermati permasalahan ini dengan baik maka akan berdampak pada tugas dan tanggung jawab dalam melayani, bahkan tidak ada motivasi untuk terlibat dalam pelayanan apa pun.

Jika hal itu sedang terjadi alangkah baiknya gereja segera menemukan apa yang pemuda cari dan harapkan saat ini. Dalam menjawab kebutuhan tersebut maka pengaruh peran gembala sidang dalam mengajar sangat dibutuhkan, karena kaum muda sedang ada dalam transisi kehidupan menuju kedewasaan hidup. Untuk menanamkan pemahaman kepada orang lain sangat diperlukan namanya pengajaran. Gereja sebagai persekutuan orang-orang percaya bertugas melaksanakan perintah Tuhan yaitu membawa anak muda kepada pertumbuhan rohani dan kedewasaan iman di dalam Kristus. Artinya bahwa kaum muda harus dibawa kepada perjumpaan pribadi dengan Kristus, serta dapat mempraktekkan imannya dalam kehidupan sehari-sehari. Oleh sebab itu, gereja harus berfungsi sebagai wadah untuk pembelajaran baginya. Pemuda perlu diajar secara terencana dan dengan sungguh-sungguh supaya pemuda tersebut terlibat dalam pelayanan secara maksimal dan memiliki pertumbuhan rohani melalui pengenalan akan Tuhan.

Menurut hemat peneliti bahwa jika gembala tidak memiliki kemampuan dalam mengajar firman Tuhan dengan benar maka domba-dombanya akan berjalan sesuai dengan kemampuannya sendiri, karena tugas seorang gembala adalah melayani dan memberi makanan rohani yang baik sesuai dengan kebenaran firman Tuhan.

Berdasarkan uraian pada latar belakang dan pembatasan masalah, maka rumusan masalahnya sebagai berikut: Pertama, seberapa besar pengaruh peran gembala sidang dalam mengajar berdasarkan 1 Timotius 4:1-16. Kedua, seberapa besar pengaruh peran gembala sidang dalam memotivasi kaum muda berdasarkan 1 Timotius 4:1-16. Ketiga, seberapa besar pengaruh peran gembala sidang dalam mengajar dan memotivasi kaum muda berdasarkan 1 
Timotius 4:1-16 terhadap pertumbuhan rohani pemuda di GKII Shalom.

Berdasarkan rumusan masalah tersebut di atas, maka tujuan penelitian ini adalah: Pertama, untuk mengetahui seberapa besar peran pengaruh gembala sidang dalam mengajar berdasarkan 1 Timotius 4:1-16. Kedua, untuk mengetahui seberapa besar peran gembala sidang dalam memotivasi kaum muda berdasarkan 1 Timotius 4:1-16. Ketiga, untuk mengetahui seberapa besar pengaruh peran gembala sidang dalam mengajar dan memotivasi kaum muda berdasarkan 1 Timotius 4:1-16 terhadap pertumbuhan rohani pemuda di GKII Shalom.

Berdasarkan rumusan masalah tersebut di atas, maka tujuan penelitian ini adalah: Pertama, untuk mengetahui seberapa besar peran pengaruh gembala sidang dalam mengajar berdasarkan 1 Timotius 4:1-16. Kedua, untuk mengetahui seberapa besar peran gembala sidang dalam memotivasi kaum muda berdasarkan 1 Timotius 4:1-16. Ketiga, untuk mengetahui seberapa besar pengaruh peran gembala sidang dalam mengajar dan memotivasi kaum muda berdasarkan 1 Timotius 4:1-16 terhadap pertumbuhan rohani pemuda di GKII Shalom.

\section{METODE}

Dalam melengkapi data penelitian ini, peneliti mengadakan penelitian lapangan supaya isi penelitian ini dapat dibuktikan kebenarannya, tetapi dalam kegiatan penelitian selalu menggunakan caracara atau langkah-langkah tertentu agar dapat mencapai pengetahuan yang benar. Jadi metodologi penelitian yang digunakan oleh peneliti adalah metode penelitian kuantitatif deskriptif. Singarimbun (1989) mendefinisikan bahwa metode deskriptif ialah memberikan gambaran tentang fenomena tertentu atau aspek kehidupan tertentu dari masyarakat yang diteliti. Sedangkan Rosenberg (1968) memberikan dua pengertian metode deskriptif, yaitu: (1) mendeskripsikan gejala-gejala yang diteliti, (2) Mempelajari hubungan antara gejala-gejala yang diteliti. Jadi, menurut Surachmad (1980:139) menjelaskan bahwa metode deskriptif tidak hanya terbatas pada pengum- pulan data, tetapi meliputi analisis dan interprestasi tentang arti data itu. Penelitian deskriptif membandingkan persamaan dan perbedaan fenomena tertentu. Setelah metode ditetapkan, berikutnya ditentukan teknik pengumpulan data yang sesuai dengan metode yang dipakai dalam penelitian ini. Tempat atau lokasi penelitian adalah pemuda-pemudi GKII Shalom. Waktu penelitian selama 6 bulan, yaitu dimulai bulan Januari sampai bulan Juni 2016.

Metode pengumpulan data adalah cara yang digunakan untuk mengumpulkan data (Husaini \& Purnomo, 2000, p. 138). Arikunto (2006, p. 67) menandaskan bahwa observasi/penelitian adalah suatu istilah umum yang mempunyai arti semua bentuk penerimaan data yang dilakukan dengan cara merekam kejadian, menghitungnya, mengukurnya dan mencatatnya. Oleh karena itu, metode pengumpulan data merupakan suatu usaha sadar untuk mengumpulkan data yang dilakukan secara sistematis, dengan prosedur terstandar. Dalam penelitian ini, metode pengumpulan data yang digunakan adalah sebagai berikut:

Pertama, angket (Quesioner). Kuesioner merupakan teknik pengumpulan data yang dilakukan dengan cara memberi seperangkat pertanyaan atau pertanyaan tertulis kepada responden untuk dijawab. Kuesioner merupakan teknik pengumpulan data yang efisien bila peneliti tahu dengan pasti variabel yang akan diukur dan tahu apa yang bisa diharapkan dari responden. Selain dari definisi di atas maka Arikunto (2006, p. 90) mendefenisikan kuesioner adalah sejumlah pertanyaan tertulis yang digunakan untuk memperoleh informasi dari responden dalam arti laporan tentang pribadinya atau hal-hal yang dia ketahui. Artinya pembuatan kuesioner adalah untuk memperoleh informasi yang relevan dengan tujuan survei dan memperoleh informasi yang reliabilitas dan validitas setinggi mungkin.

Kedua, wawancara. Wawancara atau interview adalah suatu bentuk komunikasi verbal jadi semacam percakapan yang bertujuan memperoleh informasi. Wawancara merupakan alat penelitian yang lebih sistematis. Wawancara berfungsi secara des- 
kriptif maksudnya dapat melukiskan dunia secara kenyataan seperti yang dialami orang lain dan juga berfungsi secara eksploratif maksudnya dapat meneliti bila masalah dihadapi masih samar-samar (Nasution, 2011, p. 113-114). Wawancara ini dilakukan untuk mengetahui keadaan seseorang dan mencari informasi mengenai suatu permasalahan. Tipe wawancara yang dilakukan pada penelitian ini adalah dengan wawancara bebas tetapi juga mengingat data apa saja yang akan dikumpulkan.

Ketiga, observasi. Observasi terstruktur adalah observasi yang telah dirancang secara sistematis, tentang apa yang diamati, kapan dan di mana tempatnya (Arikunto, 1997, p. 90). Observasi ialah pengamatan dan pencacatan yang sismatis terhadap gejalagejala yang diteliti. Jadi, observasi adalah metode pengumpulan data dimana peneliti mencatat informasi yang dapat pada saat melakukan pengamatan.

Responden dalam penelitian ini adalah populasi dari penelitian. Sebab populasi adalah keseluruhan subyek penelitian (Arikunto, 1997, p. 108). Sedangkan menurut Margono (1997, p. 118) populasi adalah seluruh data yang menjadi perhatian khusus dalam suatu ruang lingkup dan juga waktu yang telah tentukan. Dari kedua pendapat ini dapat ditarik kesimpulan bahwa populasi adalah jumlah keseluruhan yang lengkap dari unit analisa yang ciri-cirinya akan diduga. Sementara sampel adalah sebagian atau wakil populasi yang diteliti (Arikunto, 1997, p. 109). Saifuddin Azwar (1997, p. 79) mendefinisikan sampel adalah sebagian dari populasi. Dari pengertian di atas, dapat ditarik kesimpulan bahwa sampel adalah sebagian dari populasi yang memiliki sifat yang sama dengan populasi. Jadi, penelitian yang digunakan oleh peneliti dalam penelitian adalah populasi berdasarkan pengertian Arikunto dan Margono di atas.

Dari kedua pendapat ini dapat ditarik kesimpulan bahwa populasi adalah jumlah keseluruhan yang lengkap dari unit analisa yang ciri-cirinya akan diduga. Jadi, populasi yang diambil adalah kaum muda yang ada di GKII Shalom. Wawancara Agan (2016) diperoleh data bahwa jumlah pemuda yang ada di GKII Shalom adalah kurang lebih 30 orang. Pengambilan populasi sebagai subjek penelitian ini didasarkan pada pendapat Arikunto (1997, p. 112) yang menyatakan bahwa apabila subjeknya kurang dari 100, lebih baik diambil semua sehingga penelitiannya merupakan penelitian populasi. Dari data tersebut, maka jumlah pemuda yang diteliti oleh peneliti adalah sebanyak 30 orang. Dalam mengumpulkan data tersebut, peneliti menyebarkan kuisioner atau angket dengan menggunakan Skala Likert, yaitu sangat setuju yang diberi nilai 5, setuju diberi nilai 4, ragu-ragu diberi nilai 3 , tidak setuju diberi nilai 2 , dan sangat tidak setuju diberi 1 yang bertujuan untuk mengetahui hasil yang nyata dari penelitian tersebut. Penelitian ini menggunakan teknik analisis data statistik untuk pengumpulan, pengolahan, penafsiran, dan pembuat-an kesimpulan dalam bentuk angka-angka. Menurut Nanang (2010, p. 3) mengatakan bahwa statistik di-maksud adalah deskriptif yaitu membuat kesimpulan yang hanya berlaku pada tingkat sampel dan dilan-jutkan dengan statistik inferensial (menganalisis data sampel dan hasilnya digeneralisasi di tingkat popu-lasi tempat sampel diambil).

\section{HASIL DAN PEMBAHASAN}

\section{Hasil}

Pada bagian ini peneliti akan menjelaskan ta-hapan dalam pengolahan data yang diperoleh melalui angket dengan 30 responden. Peneliti menggunakan uji korelasi. Uji korelasi sederhana digunakan untuk mengetahui keeratan hubungan antara dua variabel dan untuk mengetahui arah hubungan yang terjadi (Priyatno, 2009, p. 53). Adapun proses pengolahan data dengan menggunakan program SPSS 19 dengan hasil sebagai berikut:

Adapun hasil uji korelasi model spearmen sebagai berikut: 


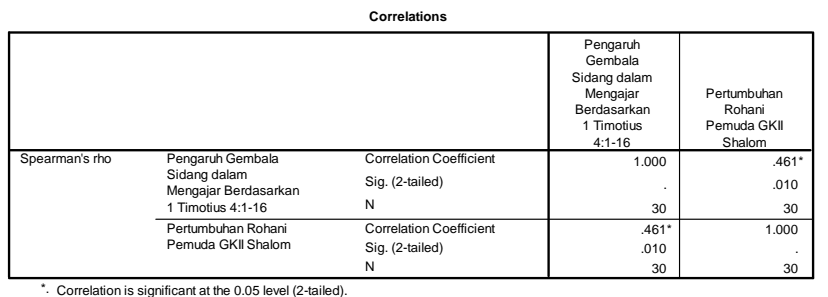

Tabel 1. Korelasi Pengaruh Gembala Sidang Dalam

Mengajar Terhadap Pertumbuhan Rohani

Pertama, Pengaruh peran Gembala Sidang dalam Mengajar Pertumbuhan Rohani Pemuda GKII Shalom Kalasan $\left(\mathrm{X}_{1}-\mathrm{Y}\right)$

Berdasarkan hasil analisis korelasi (r) model Spearmen di atas, maka diperoleh hasil analisis korelasi bahwa ada korelasi antara pengaruh peran gembala sidang dalam mengajar dengan pertumbuhan rohani pemuda GKII Shalom Kalasan sebesar 0,461. Hal ini menunjukkan terjadi hubungan yang sedang antara pengaruh peran gembala sidang dalam mengajar dengan pertumbuhan rohani pemuda GKII Shalom Kalasan.

Kedua, Pengaruh peran Gembala Sidang dalam Memotivasi Kaum Muda untuk Melayani dengan Pertumbuhan Rohani Pemuda GKII Shalom Kalasan $\left(\mathrm{X}_{2}-\mathrm{Y}\right)$.

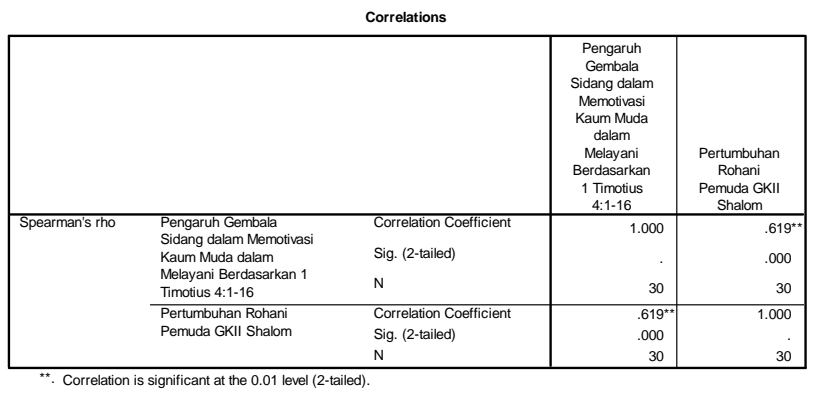

Tabel 2. Korelasi Pengaruh Gembala Sidang Dalam

Memotivasi Terhadap Pertumbuhan Rohani

Berdasarkan hasil analisis korelasi (r) model Spearmen di atas, maka diperoleh hasil analisis korelasi bahwa ada korelasi antara pengaruh peran gembala sidang dalam mengajar dengan pertumbuhan rohani pemuda GKII Shalom Kalasan sebesar 0,619. Hal ini menunjukkan terjadi hubungan yang kuat antara pengaruh peran gembala sidang dalam memotivasi kaum muda dalam melayani dengan pertumbuhan rohani pemuda GKII Shalom Kalasan.
Ketiga, Pengaruh peran Gembala Sidang dalam Mengajar dan Memotivasi Kaum Muda untuk Melayani dengan Pertumbuhan Rohani Pemuda GKII Shalom (X-Y)

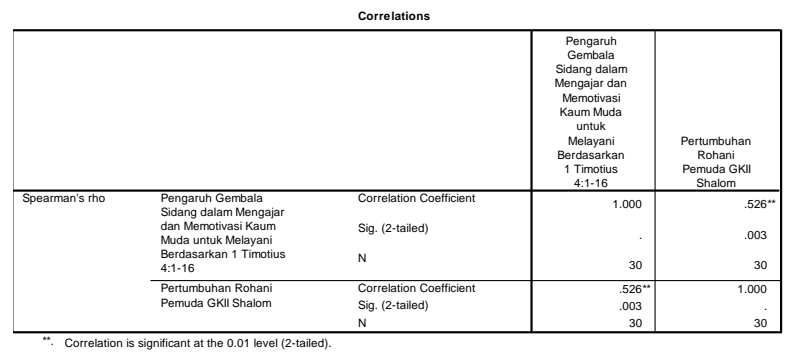

Tabel 3. Korelasi Pengaruh Gembala Sidang Dalam Mengajar dan Memotivasi untuk Melayani Terhadap Pertumbuhan Rohani

Berdasarkan hasil analisis korelasi (r) model Spearmen di atas, maka diperoleh hasil analisis korelasi bahwa ada korelasi antara pengaruh peran gembala sidang dalam mengajar dan memotivasi kaum muda untuk melayani dengan pertumbuhan rohani pemuda GKII Shalom Kalasan sebesar 0,526. Hal ini menunjukkan terjadi hubungan yang sedang antara pengaruh peran gembala sidang dalam memotivasi kaum muda dalam melayani dengan pertumbuhan rohani pemuda GKII Shalom Kalasan.

Selain analisis korelasi peneliti juga menggunakan analisis determinasi dalam menguji hipotesis. Analisis ini digunakan untuk mengetahui persentase sumbangan pengaruh variabel $\left(\mathrm{X}_{1}, \mathrm{X}_{2}, \ldots \mathrm{X}_{\mathrm{n}}\right)$ secara serentak terhadap variabel dependen (Y). Koefisien ini menunjukkan seberapa besar persentase variasi variabel independen yang digunakan dalam model mampu menjelaskan variasi variabel dependen (Priyatno, 2009, p. 79). Adapun hasil analisis determinasi tersebut sebagai berikut:

Keempat, Hasil Analisis Determinasi $\left(\mathrm{R}^{2}\right)$

\begin{tabular}{|l|r|r|r|r|}
\hline Model Summary \\
\hline 1 & $\mathrm{R}$ & $\mathrm{R}$ Square & $\begin{array}{c}\text { Adjusted } \\
\text { R Square }\end{array}$ & $\begin{array}{c}\text { Std. Error of } \\
\text { the Estimate }\end{array}$ \\
\hline & $.513^{\mathrm{a}}$ & .263 & .237 & 7.904 \\
\hline
\end{tabular}

Tabel 4. Model Summary 
Berdasarkan tabel di atas diperoleh angka $\mathrm{R}_{2}$ (R Square) sebesar 0,263 atau 26,3\%. Hal ini menunjukkan bahwa persentase sumbangan pengaruh variabel independen (pengaruh peran gembala sidang dalam mengajar dan memotivasi kaum muda untuk melayani terhadap variabel dependen (pertumbuhan rohani pemuda GKII Shalom Kalasan sebesar $26,3 \%$, dan sisanya sebesar $73,7 \%$ dipengaruhi oleh variabel lain yang tidak dimasukkan ke dalam model penelitian ini. Adjusted R Square sebesar 0,237 adalah nilai $R$ Square yang telah disesuaikan, nilai selalu lebih kecil dari R Square dan angka bisa memiliki harga negatif dan adjusted $\mathrm{R}^{2}$ sebagai koeffisien determinasi. Standard Error of the Estimate adalah suatu ukuran banyaknya kesalahan model ini dalam memprediksikan nilai Y. Dari tabel di atas diperoleh 7,904, hal ini berarti banyaknya kesalahan dalam memprediksikan pertumbuhan rohani pemuda GKII Shalom Kalasan adalah sebesar 7,904.

Kelima, Hasil Analisis Signifikansi Koeffisien Korelasi Parsial (Uji T).

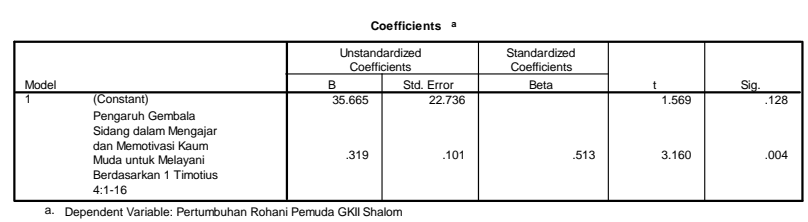

Tabel 5. Coefficients

Berdasarkan tabel Coefficients (memaparkan uji koefisien) di atas dari hasil analisis uji t menunjukkan bahwa nilai t hitung sebesar 3,160 dan t tabel sebesar 2,052. Karena syarat pengujian adalah $t$ hitung $>\mathrm{t}$ tabel, dan dari tabel di atas terlihat $\mathrm{t}$ hitung $(3,160)>$ derajat kebebasan $(\mathrm{df}=\mathrm{n}-\mathrm{k}-1, \mathrm{n}$ adalah jumlah data, $\mathrm{k}$ adalah jumlah variabel independen $=30-2-1=27$; dapat dilihat pada lampiran t tabel), maka t tabel $(2,052)$ jadi 3,160 > 2,052 maka hipotesis terbukti. Karena ada hubungan yang signifikan antara pengaruh gembala sidang dalam mengajar dan memotivasi kaum muda untuk melayani dengan pertumbuhan rohani pemuda GKII Shalom Kalasan, maka hal ini berarti hubungan tersebut berlaku untuk seluruh populasi.
Dari hasil penelitian yang diperoleh dapat disimpulkan bahwa hipotesis dalam penelitian ini dapat diterima. Jadi berdasarkan hasil penelitian secara keseluruhan dapat disimpulkan bahwa Pengaruh peran Gembala sidang dalam Mengajar dan Memotivasi Kaum Muda untuk Melayani Terhadap Pertumbuhan Rohani Pemuda GKII Shalom tahun 2016. Baik dalam hal pengertiannya terhadap Gembala sebagai pelaksana tugas mengajar, serta dalam hal gembala mengingatkan kaum muda pada ajaran yang sehat, serta gembala menasihati kaum muda pada ajaran yang sehat, dan gembala mengajarkan kaum muda sesuai dengan ajaran yang sehat. Gembala sebagai teladan berdasarkan, keteladan dalam perkataan, keteladanan dalam tingkah laku, keteladanan dalam kasih, keteladanan dalam kesetiaan, keteladanan dalam kesucian, keteladanan dalam ke-tekunanan.

Gembala sebagai pendorong, memberikan kepercayaan dengan mendelegasikan tugas, memberi motivasi yang baik bagi murid, memberi solusi pada murid. Gembala sebagai pembina, gembala mengajar pemuda di dalam Tuhan, memotivasi pemuda untuk tetap beribadah, gembala memotivasi untuk tetap berjuang dalam Tuhan. Memiliki tindakan yang benar, rajin berdoa, rajin membaca firman Tuhan, rajin merenungkan firman Tuhan. Hidup dalam firman Tuhan, taat dalam pembelajaran firman Tuhan, taat kepada Tuhan, setia beribadah kepada Tuhan.

Dengan demikian hipotesis dalam penelian ini adalah ada pengaruh peran gembala sidang dalam mengajar dan memotivasi kaum muda untuk melayani terhadap pertumbuhan rohani kaum muda GKII Shaaom Kalasan. Jadi, hipotesis tersebut adalah di terima berdasarkan analisis di atas. Berdasarkan temuan tersebut, Wagner (1998, p.173) mengatakan bahwa tugas utama seorang gembala adalah mengajar dan memberitakan Injil. Pemberitaan Injil adalah alat utama bagi pertumbuhan iman anggota jemaah atau pemuda. Artinya bahwa fungsi gembala jemaat ialah memimpin anggota jemaat untuk menjadi dewasa dalam firman Tuhan agar bisa mengambil keputusan yang tidak bertentangan dengan firman Tuhan serta membangun jemaat atau pemuda. 
Jadi, pengaruh gembala sidang dalam mengajar dan memotivasi kaum muda untuk melayani sangat penting untuk di tingkatkan dan dicermati oleh seorang gembala sidang berkenan dengan pertumbuhan rohani kaum muda masa kini.

\section{Pembahasan}

Setelah melakukan analisis korelasi (r) model Spearmen terhadap ketiga sub varibel, yakni $\mathrm{X}_{1}$ $\mathrm{Y}, \mathrm{X}_{2}-\mathrm{Y}$ dan $\mathrm{X}-\mathrm{Y}$ di sana terdapat perbedaan hasil analisis antara sub variabel $\mathrm{X}_{1}-\mathrm{Y}, \mathrm{X}_{2}-\mathrm{Y}$ dan $\mathrm{X}-\mathrm{Y}$. $\mathrm{X}_{1}-\mathrm{Y}$ ada korelasi antara pengaruh peran gembala sidang dalam mengajar dengan pertumbuhan rohani pemuda GKII Shalom Kalasan sebesar 0,461 dan X$\mathrm{Y}$ ada korelasi antara pengaruh peran gembala sidang dalam mengajar dan memotivasi kaum muda untuk melayani dengan pertumbuhan rohani pemuda GKII Shalom Kalasan sebesar 0,526. Kedua sub variabel ini memiliki kesamaan antara sub variabel pertama dan sub variabel ketiga bahwa adanya hubungan yang sedang. Sedangkan sub varibel kedua adalah $\mathrm{X}_{2}-\mathrm{Y}$ ada korelasi antara pengaruh peran gembala sidang dalam mengajar dengan pertumbuhan rohani pemuda GKII Shalom Kalasan sebesar 0,619 . Hal ini menunjukkan terjadi hubungan yang kuat. Berarti tidak semua sub variabel memiliki pengaruh yang kuat terhadap pengaruh peran gembala sidang dalam mengajar dan memotivasi kaum muda untuk melayani terhadap pertumbuhan rohani kaum muda GKII Shalom Kalasan.

Menurut Sanders (2006, p. 9) menjadi gembala sidang bukan karena ia memilih jabatan itu, melainkan sebab ia taat pada penggilan Ilahi. Di sinilah letak pentingnya peran gembala sebagai pengajar dan motivator untuk menunjukkan relevansi firman Tuhan yang begitu kaya tentang bagaimana caranya hidup bertumbuh dan lebih baik dari hari ke hari. Gereja saat ini sangat membutuhkan adanya gembala yang memiliki kemampuan dalam mengajar dan memotivator kaum muda. Karena kehidupan kaum muda perlu diarahkan pada tujuan yang jelas sehingga mengalami pembaruan hidup yang lebih baik serta memiliki kedewasaan secara intelektual dan iman. Jika kemampuan ini diarahkan dan dimanfaatkan secara sadar dan integral, maka potensi pemuda yang secara kwantitatif sangat besar itu akan sangat menentukan dalam pencapaian tujuan program pembangunan gereja kelak. Jadi, gereja seharusnya berperan aktif dalam menangani generasi ini, agar generasi muda ini tidak salah arah. Sadar tidak atau tidak sadar bahwa banyak kaum muda yang mengalami kemorosotan moral dan iman dalam lingkungan gereja saat ini, bahkan tidak sedikit diantaranya meninggalkan imannya hanya karena dirinya tidak mendapat apa-apa dalam gereja. Dalam sebuah buku "You Lost Me - Mengapa Orang Kristen Muda Meninggalkan Gereja" (Kinnaman, 2011) penulisnya menguraikan beberapa persoalan yang berkaitan dengan anak-anak muda, yang pergi meninggalkan gereja antara lain: Pertama, gereja tidak mendidik dan memperlengkapi mereka untuk hidup di tengah masyarakat. Kedua, gereja terlalu mengangkat mereka ke "awan-awan surgawi" dan membuat mereka tidak bisa menerangi dan menggarami dunia, di dalam bidang mereka masing-masing. Ketiga, gereja tidak mengerti dunia dan kebutuhan anak muda. Keempat, gereja kekurangan pengerja khususnya dalam melayani pemuda, yang sanggup memperlengkapi anak muda dalam bidang ilmu pengetahuan. Kelima, 1 dari 100 pendeta muda/pengerja gereja kaum muda yang mampu membawa mereka pada kenyataan bahwa iman dan ilmu pengetahuan dapat hidup berdampingan. Keenam, gereja dipandang tidak siap menghadapi pertanyaan-pertanyaan demikian (David, 2011). Menurut Homrighausen dan Enklaar (2004, p. 141) bahwa seorang anak belum sanggup berpikir secara abstrak, tetapi pemuda dapat mempergunakan daya pikirannya makin lama makin tajam dan baik. Ia memikirkan segala masalah hidup manusia yang hangat, tentang arti dan tujuan hidup ini, tentang soal nikah dan pekerjaan, tentang kedudukan dan fungsinya dalam masyarakat, tentang panggilan dan tugasnya, tentang penyakit dan ketidakadilan, tentang kematian dan Allah.

Hasil penelitian menunjukkan pentingnya peran gembala dalam memotivasi pemuda sehingga 
pemuda dapat mengalami perubahan sesuai dengan tujuan. Hamalik (2007, p. 58) mengemukakan bahwa motivasi adalah perubahan energi dalam diri seseorang yang ditandai dengan timbulnya perasaan dan reaksi untuk mencapai tujuan. Demikian pula hasil penelitian menunjukan bahwa dengan adanya motivasi maka terjadi pertumbuhan rohani. Pertumbuhan rohani adalah mengalami tingkat kedewasaan penuh dalam iman kepada Tuhan Yesus, dan hidup menurut prinsip-prinsip kebenaran firman Tuhan (Hardono, 2003, p. 38). Jadi, pertumbuhan rohani pemuda, mengalami pertumbuhan karena pengenalan akan Kristus yang semakin mendalam. Pengenalan terjadi karena bersekutu dan bergaul dengan Kristus setiap hari.

\section{KESIMPULAN}

Berdasarkan hasil pengolahan data dan pembahasan yang diperoleh melalui penyusunan instru-

\section{DAFTAR RUJUKAN}

Agan, Lie. 2016. Wawancara, Gembala Sidang Gereja Kemah Injil Indonesia Shalom, Minggu 16 Maret, Yogyakarta.

Alkitab, 2008. Jakarta: Lembaga Alkitab Indonesia.

Arikunto, S. 1997. Prosedur Penelitian Suatu Pendekatan Praktek. Jakarta, Penerbit Rineka Cipta.

Ayub, R. 2011. Kepemimpinan Kharismatis-Tinjauan Teologis atas Kepemimpinan Kharismatis Sukarno. Jakarta: BPK Gunung Mulia

Blaiklock, E.M. 1981. Surat-surat Penggembalaan. Malang: Gandum Mas

Departeman Pendidikan dan Kebudayaan. 1996. Kamus Besar Bahasa Indonesia. Jakarta: Balai Pustaka.

Everett, F. H. 2008. Tafsiran Alkitab Wycliff, Vol. 3: Perjanjian Baru. Malang: Gandum Mas.

Hamalik, O. 2007. Proses Belajar Mengajar. Jakarta: Bumi Aksara.

Hardono, M. 2003. Pelajaran Kelompok Sel. Jakarta: GBI. Sungai Yordan. men, pengumpulan data, dan analisis data mengenai Pengaruh peran Gembala sidang dalam Mengajar dan Memotivasi Kaum Muda untuk Melayani Berdasarkan 1 Tim. 4:1-16 Terhadap Pertumbuhan Rohani Pemuda GKII Shalom Kalasan dengan memiliki scor yang sangat memuaskan. Dengan demikian, tugas utama seorang gembala adalah mengajar dan memberitakan Injil. Pemberitaan Injil adalah alat utama bagi pertumbuhan iman kaum muda. Artinya bahwa fungsi gembala sidang ialah memimpin anggota kaum muda untuk menjadi dewasa dalam firman Tuhan agar bisa mengambil keputusan yang tidak bertentangan dengan firman Tuhan. Oleh karena itu, pengaruh gembala sidang dalam mengajar dan memotivasi kaum muda untuk melayani sangat penting untuk di tingkatkan dan dicermati oleh seorang gembala sidang berkenan dengan pertumbuhan rohani kaum muda saat ini.

Homrighausen, E.G. \& I.H. Enklaar. 2004. Pendidikan Agama Kristen. Jakarta: BPK Gunung Mulia.

Kinnaman, D. 2011. You Lost Me: Mengapa Orang Kristen Muda Meninggalkan Gereja Dan Memikirkan Ulang Tentang Iman Mereka, Malang: STT Aletheia.

Lebar, L.E. 2006. Education That Is ChristianProses Belajar Mengajar Kristiani \& Kurikulum yang Alkitabiah. Malang: Gandum Mas.

Mardalis. 2003. Metode Penelitian, Suatu Pendekatan Proposal. Jakarta: Bumi Aksara.

Margono. S. 1997. Metodologi Penelitian Pendidikan. Jakarta: PT. Rineka Cipta.

McDermott, Gerald R. 2001. Mengenali 12 Tanda Kerohanian Sejati. Yogyakarta: Andi Offset Yogyakarta.

Moulton, Haroul K. 2009. Lesikon Analitis Bahasa Yunani Yang Direvisi, Pen. Robert Leland dan Stanley Pouw. Yogjakarta: Randa's Family Press. 
Nanang, M. 2010. Statistik Sosial: Teori dan Aplikasi Program SPSS. Yogyakarta: Gava Media.

Nubantimo, Ebenhaizer I. 2009. Aku memahami yang aku iman. Jakart: Gunung Mulia.

Nygren, A. 1982. Agape and Eros. London: SPCK.

Priyatno, D. 2009. Mandiri Belajar SPSS. Yogyakarta: Mediakom.

Rice, H. 2006. Managemen Umat. Bandung: Yayasan Kalam Hidup.

Roberts. 1988. Hidup Suci: Panggilan Bagi Setiap Orang Kristen, Bandung: Lembaga Literatur Baptis.

Rudy, B. 2008. Tafsiran Alkitab Surat-Surat Pastoral I \& II Timotius dan Titus. Jakarta: BPK Gunung Mulia

Sanders, J. O. 2006. Kepemimpinan Rohani. Bandung: Yayasan Kalam Hidup.

Sedjaya. 2004. Kepemimpinan Kristen. Jakarta: Kairos.

Sidjabat, B.S. 2011. Mengajar Secara Profesional. Bandung: Yayasan Kalam Hidup.

Sugono, D. 2008. Kamus Besar Bahasa Indonesia. Jakarta: Pusat Bahasa.
Susanto, H. 2006a. Perjanjian Baru Interlinear Yunani-Indonesia dan Konkordansi Perjanjian Baru (PBIK). Jakarta: LAI.

Susanto, H. 2006b. Perjanjian Baru Interlinear Yunani-Indonesia dan Konkordansi Perjanjian Baru (PBIK), Jilid II: Konkordansi Perjanjian Baru. Jakarta: LAI.

Syukur, Nico. 2004. Teologi Sistematika 2 "Ekonomi Keselamatan. Yogyakarya: Kanisius.

Tafonao, T. 2016. Gembala Sebagai Pengajar, Motivator dan Inspirator. Yogyakarta: IllumiNation.

Wagner, P.C. 1998. Manfaat Karunia Roh. Malang: Gandum Mas.

Walls, A.F. 2002. "Gembala" Dalam Ensiklopedia Alkitab Masa Kini, Jilid I. (Jakarta: Yayasan Komunikasi Bina Kasih/OMF.

Winardi, J. 2007. Motivasi dan Pemotivasian dalam Manajemen. Jakarta: Raja Grafindo Persada.

www.SABDA.org di unduh pada hari selasa tanggal 15 April 2014, Pukul: 9:39 Wib

Yudho, B. 2009. How to Become Succesful Christian Entrepreneur-Kiat Menjadi Pengusaha Kristen. Yogyakarta: Andi Offset. 